\title{
BIOCHEMICAL STATUS OF HEALTHY PREMATURE INFANTS IN THE FIRST 48 HOURS OF LIFE
}

\author{
BY
}

\author{
J. YU, W. W. PAYNE, A. IFEKWUNIGWE, and J. STEVENS \\ From the Nuffield Neonatal Research Unit, Institute of Child Health, Hammersmith Hospital, London
}

(RECEIVED FOR PUBLICATION DECEMBER 4, 1964)

The development of satisfactory ultramicromethods of biochemical analysis has made it possible to carry out repeated estimations in newborn infants. At the same time, advances in knowledge of the biochemical aspects of disease processes, on which so much modern therapy is based, make it necessary to acquire a knowledge of normal values.

Serial studies of the blood chemistry of term infants have already been published (Acharya and Payne, 1965). In this paper we report similar studies on healthy premature infants in whom simultaneous measurements of a number of biochemical values were repeated at timed intervals over the first 48 hours of life.

\section{Material and Methods}

Routine Baby Care. All the babies in this study were nursed in incubators heated to between 31.6 and $33.3^{\circ} \mathrm{C}$., depending on birth weight. Extra oxygen was given even in the absence of respiratory distress in the very small premature babies, if breathing was very periodic or if the deep body temperature fell (Hill, 1961).

Most of the babies were starved for the first 12 hours of life. Feeding was begun with one feed of water followed subsequently by full strength 'pooled' expressed breast milk. Babies with birth weights below 2,000 g. were started on $4 \mathrm{ml}$. three-hourly and babies weighing from $2,000-2,500 \mathrm{~g}$. on $6 \mathrm{ml}$. three-hourly, daily increments of $32 \mathrm{ml} . / \mathrm{kg}$. day being made. In general, babies weighing less than $1,700 \mathrm{~g}$. were tube fed, the tube being repassed for each feed.

Sampling Techniques. The babies in this series were selected because of their normal clinical progress without reference to the biochemical findings.

The total number studied was 31 , of whom 6 were less than $1,500 \mathrm{~g}$. and 25 between 1,500 and $2,500 \mathrm{~g}$. Of the latter group 9 were males and 16 were females.

Blood specimens were obtained from an umbilical arterial catheter, at $1,3,6,9,12,18,24,36$, and 48 hours. In many of the babies born in the hospital, specimens of cord blood were collected. As the cycle of collections began at varying times during the day, there was no fixed relation between sampling and feeding times; however, the caloric intake of the premature infants during the first 24 hours was negligible, being between 17-26 calories.

Whole blood, $1.3 \mathrm{ml}$., was collected into a heparinized $2 \mathrm{ml}$. syringe; $0.2 \mathrm{ml}$. was immediately placed into a fluoride tube for glucose, phosphate, and lactate determination and placed in a refrigerator; $0.1 \mathrm{ml}$. was taken for $p \mathrm{H}, \mathrm{PCO}_{2}$, and bicarbonate estimation, and the remainder was centrifuged. The plasma was removed at once and refrigerated at 4 C. until the remaining estimations could be performed. The catheter was kept patent with heparinized saline.

Laboratory Methods. $p \mathrm{H}$ was determined using an E.I.L. meter with replaceable electrode system. $\mathbf{P C O}_{2}$ and standard bicarbonate were derived from a modified E.I.L. equilibration unit (Stevens and Lanning, 1964).

Sodium and potassium were estimated with an E.E.L. flame photometer; chloride by a titrimetric method using mercuric nitrate and ethanolic diphenyl carbazone; urea by Fearon's method using diacetyl monoxime; and phosphorus with the molybdic method of Fiske and Subbarow (1925). The amount of fluoride is critical because if the concentration exceeds $40 \mathrm{mg} . / 100 \mathrm{ml}$. it interferes with the phosphorus estimation, yielding low results.

The estimation of blood glucose by a modification of the method of Marks (1959), using glucose oxidase, was performed within 12 hours of collection.

Calcium and magnesium were estimated by a flame photometer (Alcock and MacIntyre, 1960); lactate by the method of Barker and Summerson (1941); pentose by Bial's method (Green, Stoner, and Bielschowsky, 1949); and amino acids by the method of Danielson (1933). The biuret method of Kingsley (1939) and Gornall, Bardawill, and David (1949) was used for protein estimation.

\section{Results}

The results are illustrated in Figs. 1-5.

pH. $p \mathrm{H}$ levels in cord blood were low with a mean of $7 \cdot 23$ in premature infants of birth weight less than $1,500 \mathrm{~g}$. They rose rapidly with the establishment of respiration to normal newborn levels. 
Rather unexpectedly, the smaller premature infants attained acid-base balance more rapidly than the bigger infants. The smaller infants reached a $p \mathrm{H} 7 \cdot 30$ by 1 hour as compared with 3 hours in larger female babies and 4 hours in male babies. These larger male infants continued to lag behind

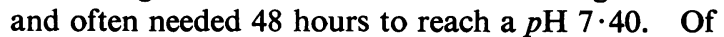
the 6 premature babies who were less than $1,500 \mathrm{~g}$. at birth, 5 reached a $p \mathrm{H} 7 \cdot 40$ by 12 hours.

Pco. $_{2}$. Male babies greater than $1,500 \mathrm{~g}$. had the highest $\mathrm{PCO}_{2}$ of the population studied. The $\mathrm{PCO}_{2}$ of these babies remained between $30 \mathrm{~mm}$. and $40 \mathrm{~mm}$. $\mathrm{Hg}$ during the first 48 hours of life. The mean values for infants less than $1,500 \mathrm{~g}$. fell between that of the heavier males and the females who, with values from $25-35 \mathrm{~mm} . \mathrm{Hg}$, were lowest.

The trend in all these groups showed a slow fall from the maximum level seen in the cord blood.

Standard Bicarbonate. The standard bicarbonate is a simple and fair estimate of metabolic acidosis. In well, premature infants, standard bicarbonate levels confirmed the rapid establishment of acid-base homeostasis suggested by a study of $p \mathrm{H}$ levels. Up to the first 6 hours of life, the smaller premature infants again had slightly higher values than larger infants, reaching a standard bicarbonate value of $20 \mathrm{mEq} / \mathrm{l}$. by 3 hours.

In infants over $1,500 \mathrm{~g}$. the over-all mean value for the male during this period was greater than that for the female by $1.8 \mathrm{mEq} / \mathrm{l}$.

The rise in bicarbonate lagged slightly behind the rise of blood $p \mathrm{H}$.

Lactic Acid. There was a wide range in serum lactate levels, in general those babies with the more difficult deliveries having the higher values. The mean lactate level in the cord blood of infants greater than $1,500 \mathrm{~g}$. was $33 \mathrm{mg} . / 100 \mathrm{ml}$. and this fell quickly to $21 \mathrm{mg}$. at 3 hours, after which the fall was more gradual, not reaching $15 \mathrm{mg}$. until 48 hours.

During this time, the lactate levels of the smaller infants remained higher than those of the heavier ones.

Sodium. The range of cord sodium levels in premature babies was wide. Those babies under $1,500 \mathrm{~g}$. tended to have higher levels $(142-163 \mathrm{mEq} / \mathrm{l}$.) which remained higher than the mean for those babies heavier than $1,500 \mathrm{~g}$. throughout the 48 hours of study. The larger babies showed cord levels 116-142 with a mean of $132 \cdot 4 \mathrm{mEq} / \mathrm{l}$. No prenatal factors influencing the cord level could be found, nor did the cord levels seem to affect or indicate later progress.
Over the first 48 hours, the serum sodium slowly rose in all babies so that at 48 hours it was $5 \cdot 0-5 \cdot 5 \mathrm{mEq} / \mathrm{l}$. higher than the lowest level reached at 1-3 hours.

Potassium. Serum potassium levels in cord blood were high by adult standards, ranging from $5 \cdot 0-10 \cdot 2$ $\mathrm{mEq} / \mathrm{l}$. By 1 hour the level had fallen, after which one-half of the babies showed a gradual and continuous fall over the next 48 hours, whereas in the remainder the serum $\mathrm{K}^{+}$again rose slowly to reach a maximum at $18-36$ hours.

After 24 hours the mean values for the lower weight group were above those for the higher, being 5.6 and $5.8 \mathrm{mEq} / \mathrm{l}$. at 24 and 36 hours as compared with $4 \cdot 6$ and $4 \cdot 4$ in the heavier group.

Chloride. The serum chloride values in premature infants were within the normal adult range of 96-106 $\mathrm{mEq} / \mathrm{l}$. throughout the 48 -hour period of study. In general, there was a gradual rise of $2-8 \mathrm{mEq} / \mathrm{l}$. in individual cases over this time. The mean values for small premature infants remained below those for infants heavier than $1,500 \mathrm{~g}$. at birth.

There was no correlation between chloride levels and PCV, nor between the chloride concentration and the clinical state of the baby.

Serum Calcium. Calcium levels in the cord blood of premature infants were high, mean $5 \cdot 3 \mathrm{mEq} / \mathrm{l}$. The calcium levels then fell to a minimum of $4 \cdot 3$ $\mathrm{mEq} / \mathrm{l}$. at 18-24 hours before rising again. The smaller premature infants of less than $1,500 \mathrm{~g}$. birth weight showed a similar trend, but their mean values were lower than those of heavier babies. In the smaller weight group, many individual low values such as $3 \cdot 2-3 \cdot 5 \mathrm{mEq} / 1$. were seen in apparently well and asymptomatic babies.

Serum Magnesium. The trends in serum magnesium levels were very similar to those of serum calcium, with a high cord level, a subsequent fall, and then recovery. The minimum levels seemed somewhat earlier, however, 12-18 hours. The smaller premature infants had lower magnesium levels than the heavier ones in the first 24 hours. At 12-18 hours, the mean was $1.3 \mathrm{mEq} / \mathrm{l}$. as compared with 1.5 in the babies over $1,500 \mathrm{~g}$., and at 48 hours $1.8 \mathrm{mEq} / \mathrm{l}$., compared with $1 \cdot 6$.

Blood Inorganic Phosphate. There was a wide range in the inorganic phosphate levels of premature infants from $3 \cdot 0-7 \cdot 4 \mathrm{mg} . / 100 \mathrm{ml}$. These levels did not correlate with the weights of the babies, or with any known factors operating at the time of birth. In 


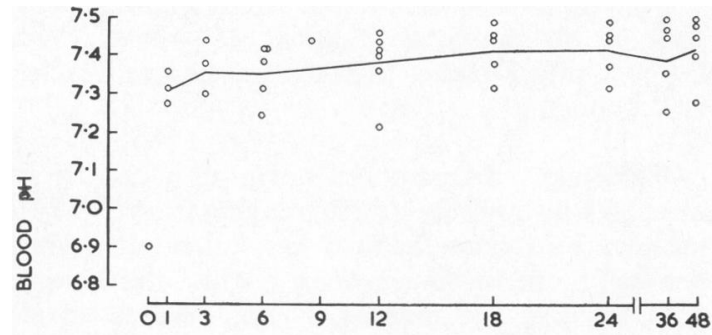

(a)

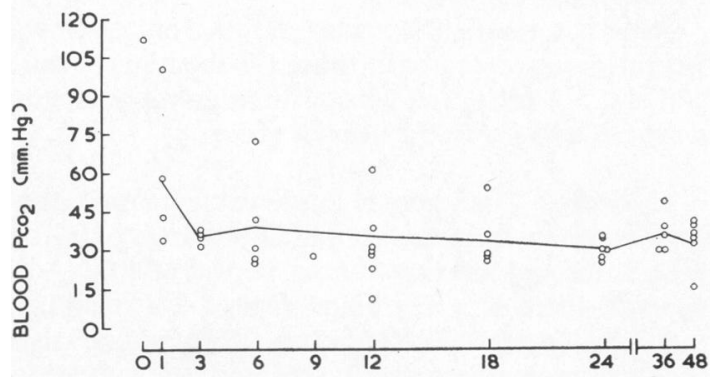

(c)

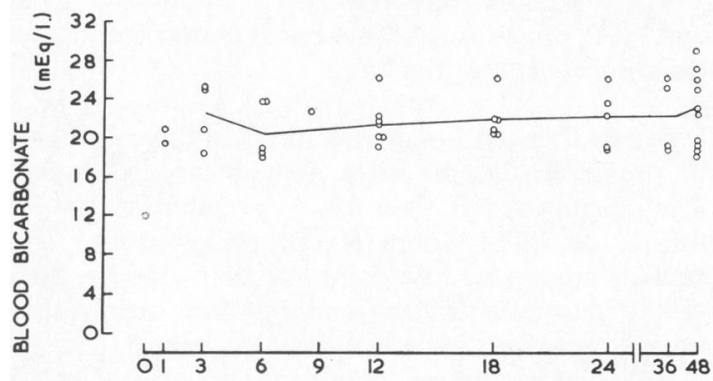

(e)

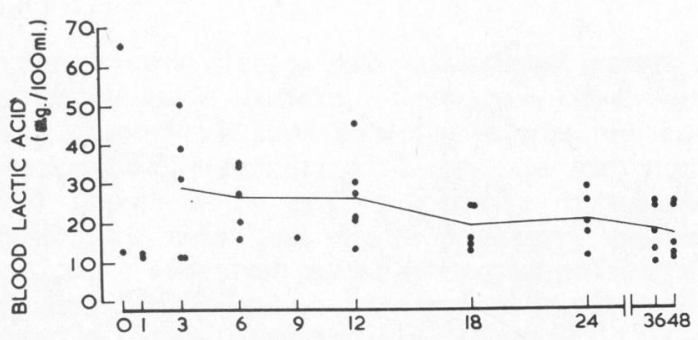

AGE IN HOURS

(g)

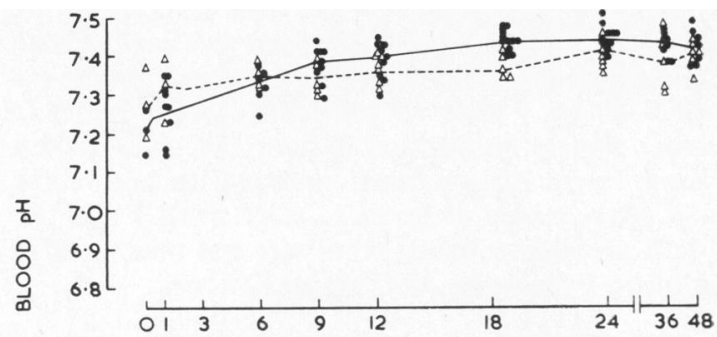

(b)

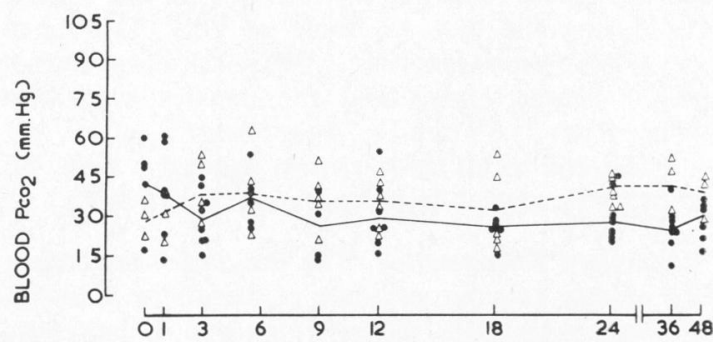

(d)

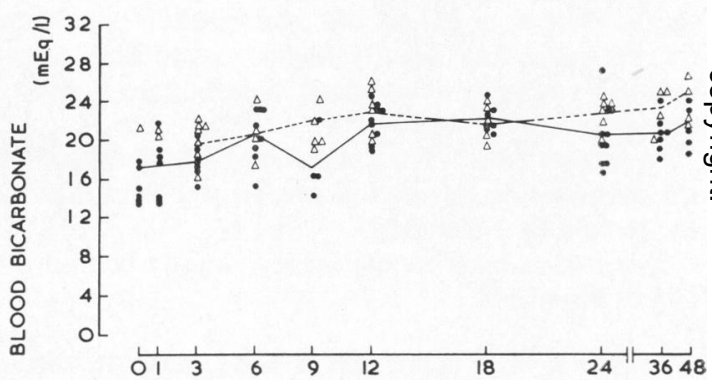

(f)

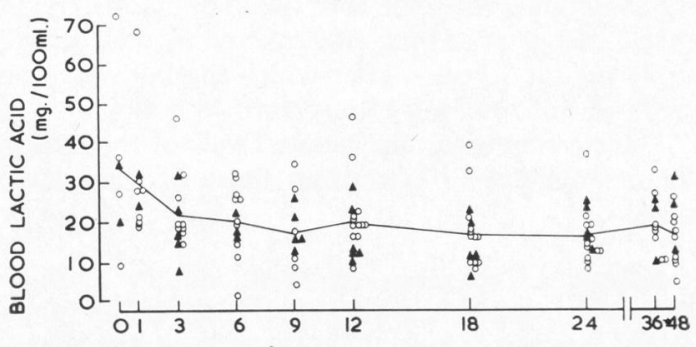

AGE IN HOURS

FIG. 1.-(a) 'Well' premature babies birth weight under 1,500 g. Serial blood $p H$ estimations with mean line. (b) 'Well' premature babies birth weight over $1,500 \mathrm{~g}$. Serial blood $p \mathbf{H}$ estimations: $\triangle$ male, female; - . - - male mean line, _- female mean line. (c) 'Well' premature babies birth weight under $1,500 \mathrm{~g}$. Serial blood $\mathbf{P C O}_{2}$ estimations with mean line. (d) 'Well' premature babies birth weight over $1,500 \mathrm{~g}$. Serial blood $\mathrm{PCO}_{2}$ estimations: $\triangle$ male, $O$ female; .... male mean line, $\_$female mean line. (e) 'Well' premature babies birth weight under $1,500 \mathrm{~g}$. Serial blood standard bicarbonate estimations with mean line. (f) 'Well' premature babies birth weight over $1,500 \mathrm{~g}$. Serial blood standard bicarbonate estimations: $\Delta$ male, $\bigcirc$ female; $\ldots .$. male mean line, $\longrightarrow$ female mean line. (g) 'Well' premature babies birth weight under $1,500 \mathrm{~g}$. Serial blood lactic acid estimations with mean line. (h) 'Well' premature babies birth weight over $1,500 \mathrm{~g}$. Serial blood lactic acid estmations: $\Delta$ male, $O$ female; with mean line of both. 


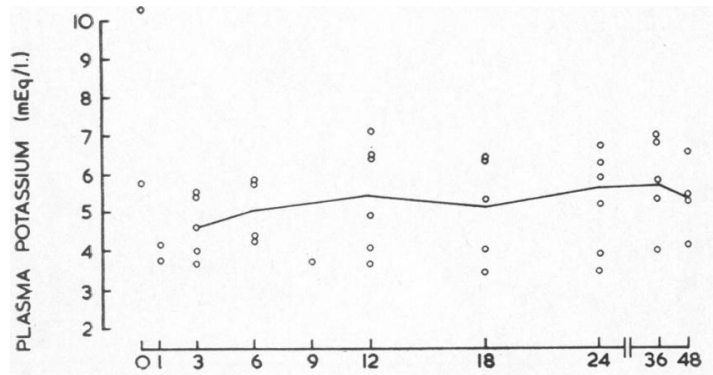

(a)

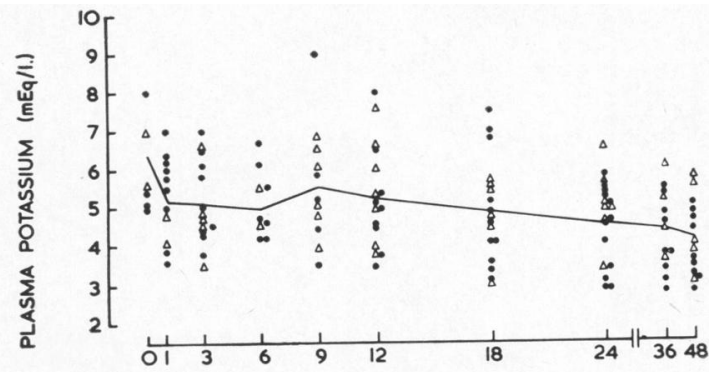

(b)
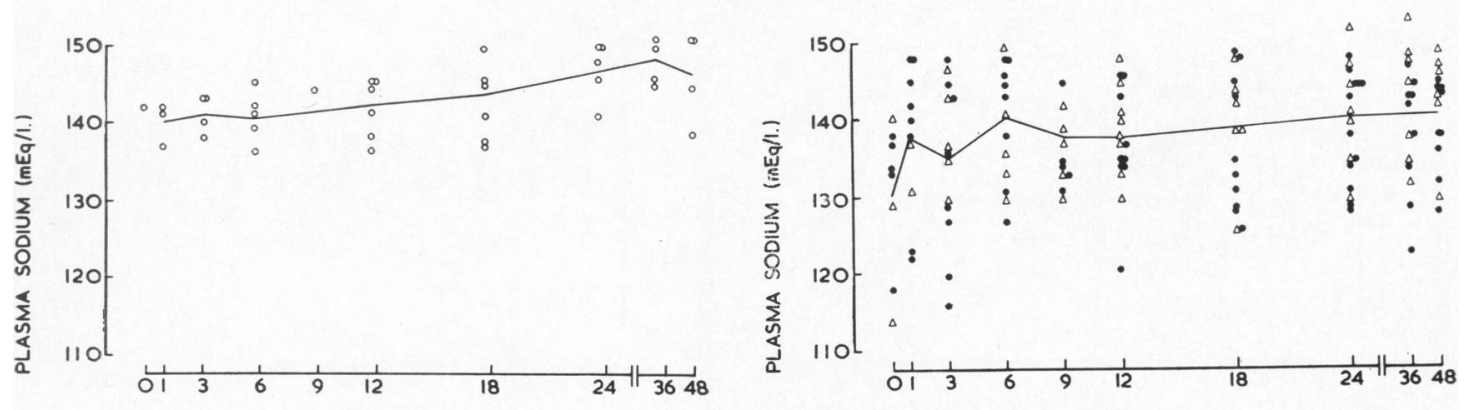

(d)

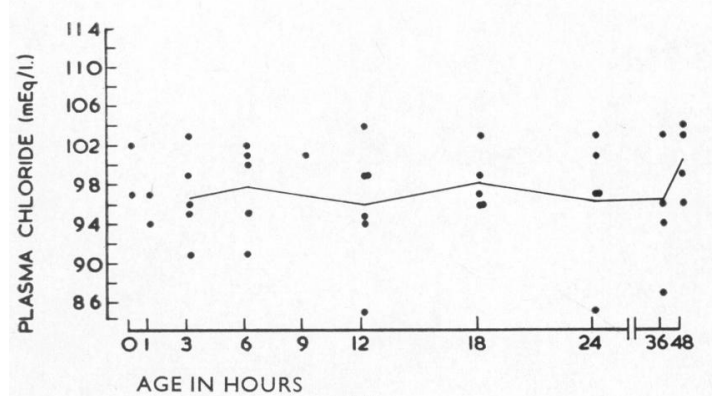

(e)

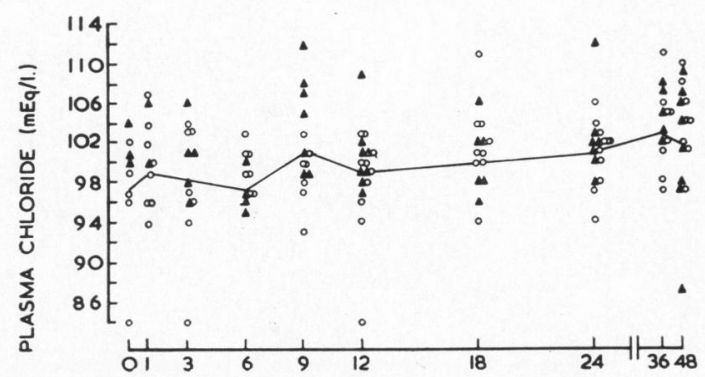

AGE IN HOURS

(f)

FIG. 2.-(a) 'Well' premature babies birth weight under 1,500 g. Serial plasma potassium estimations with mean line. (b) 'Well' premature babies birth weight over $1,500 \mathrm{~g}$. Serial plasma potassium estimations: $\triangle$ male, female; with mean line of male and female. (c) 'Well' premature babies birth weight under $1,500 \mathrm{~g}$. Serial plasma sodium estimations with mean line. (d) 'Well' premature babies birth weight over $1,500 \mathrm{~g}$. Serial plasma sodium estimations: $\triangle$ male, $O$ female; with mean line of male and female. (e) 'Well' premature babies birth weight under $1,500 \mathrm{~g}$. Serial plasma chloride estimations with mean line. (f) 'Well' premature babies birth weight over $1,500 \mathrm{~g}$. Serial plasma chloride estimations: $\triangle$ male, $O$ female; with mean line of both. 


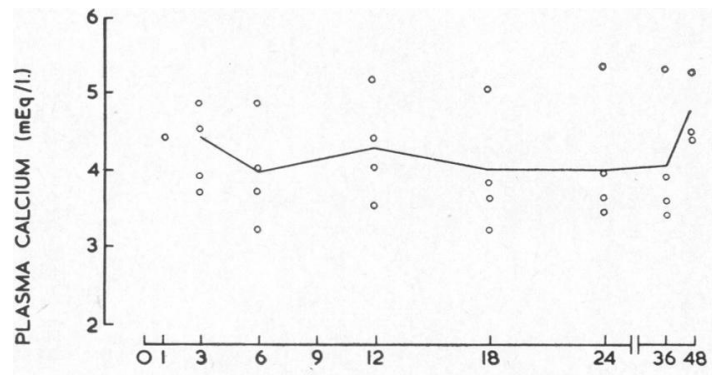

(a)

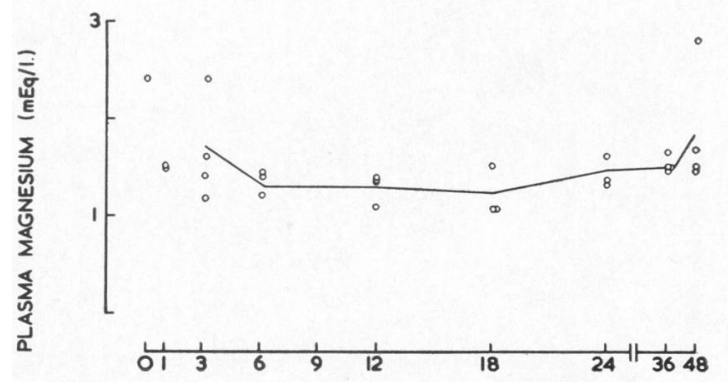

(c)

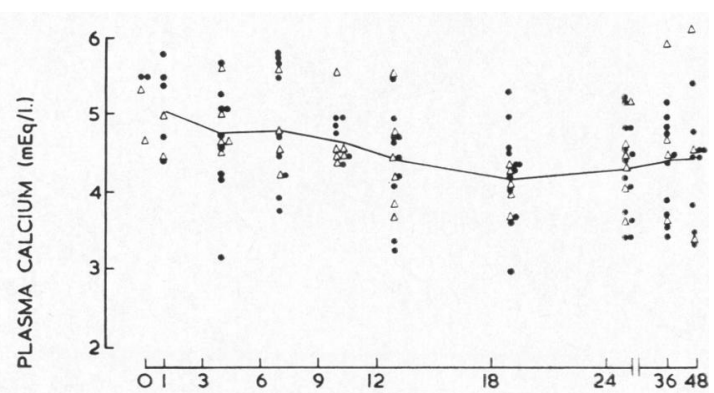

(b)

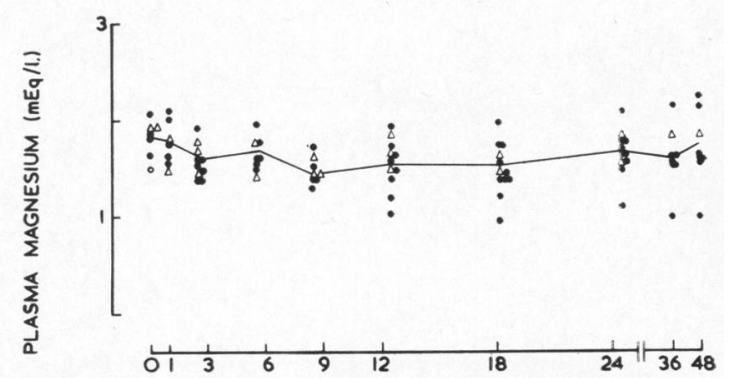

(d)

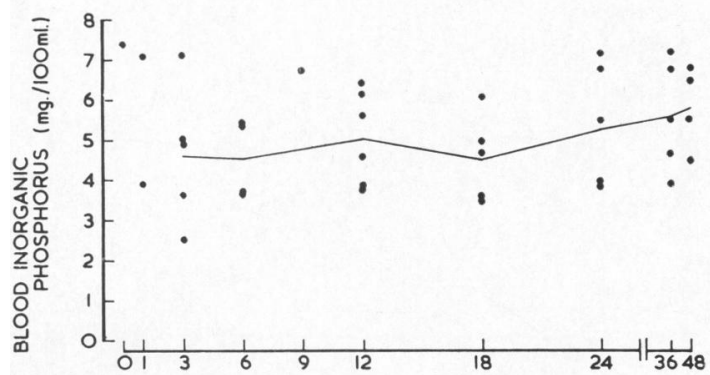

(e)

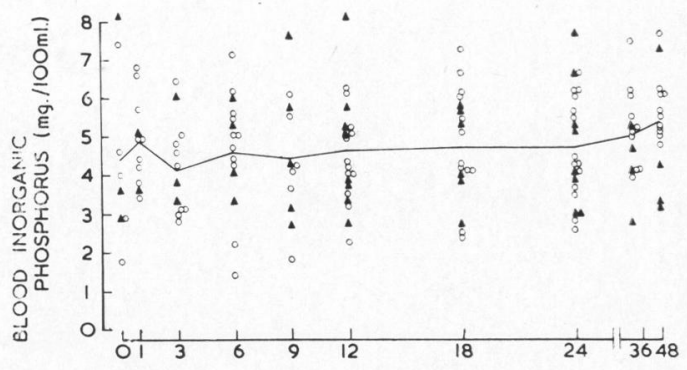

(f)

AGE IN HOURS

FIG. 3.-(a) 'Well' premature babies birth weight under 1,500 g. Serial plasma calcium estimations with mean line. (b) 'Well' premature babies birth weight over $1,500 \mathrm{~g}$. Serial plasma calcium estimations: $\triangle$ male, female; with mean line of male and female. (c) 'Well' premature babies birth weight under $1,500 \mathrm{~g}$. Serial plasma magnesium estimations with mean line. (d) 'Well' premature babies birth weight over $1,500 \mathrm{~g}$. Serial plasma magnesium estimations: $\triangle$ male, $O$ female; with mean line of male and female. (e) 'Well' premature babies birth weight under $1,500 \mathrm{~g}$. Serial blood inorganic phosphorus estimations with mean line. (f) 'Well' premature babies birth weight over $1,500 \mathrm{~g}$. Serial blood inorganic phosphorus estimations: $\Delta$ male, $O$ female; with mean line of both. 

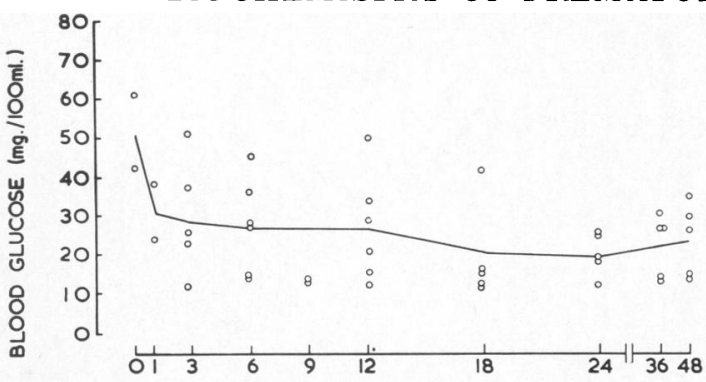

AGE IN HOURS

(a)

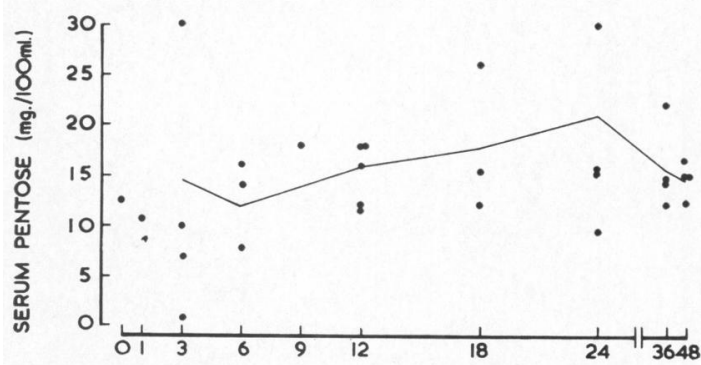

(c)

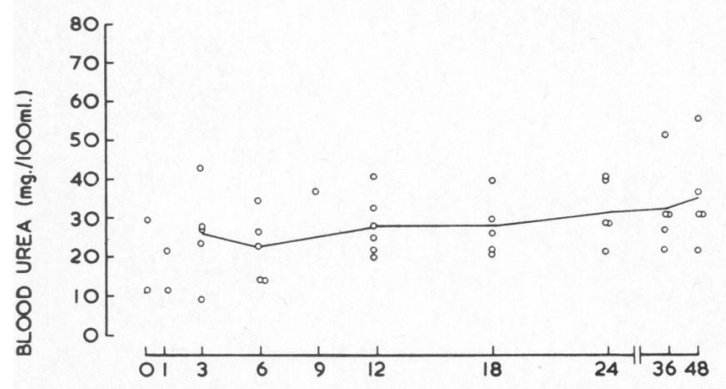

(e)

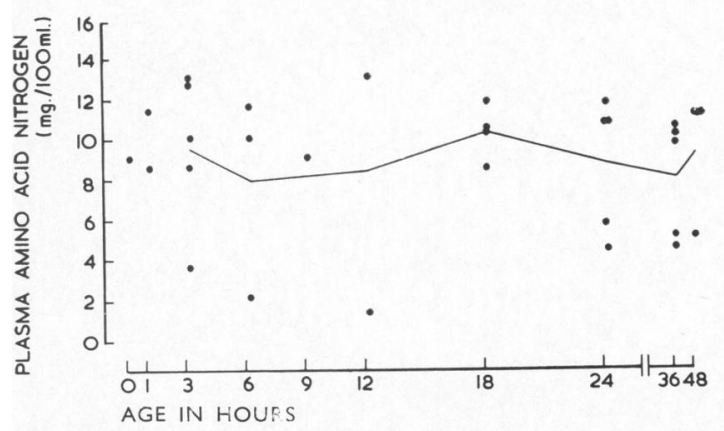

(g)

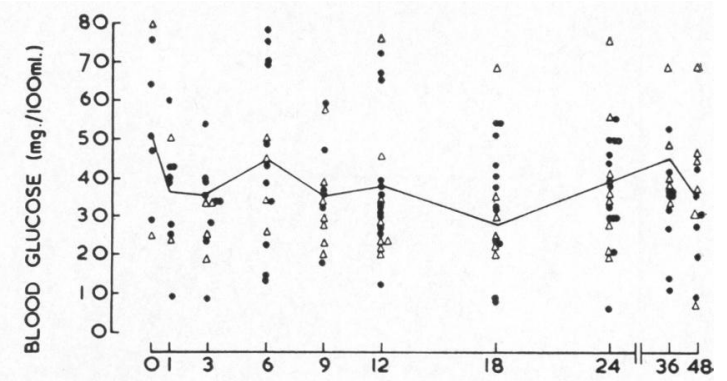

(b)

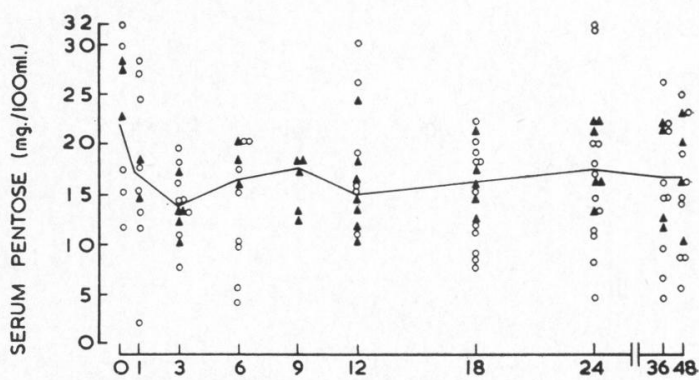

(d)

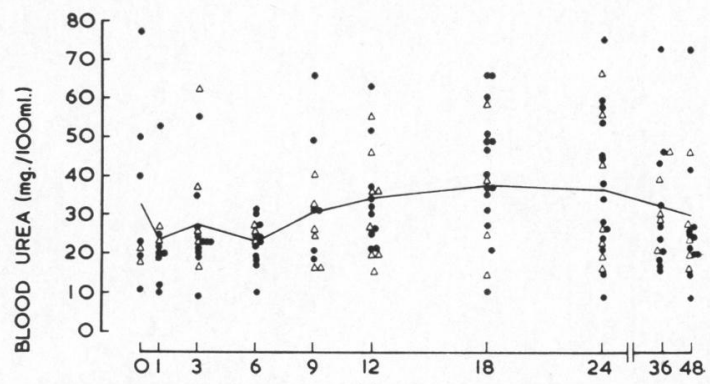

(f)

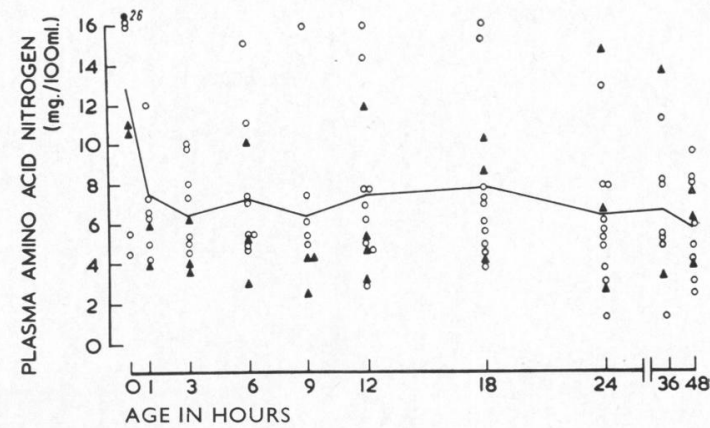

(h)

FIG. 4.-(a) 'Well' premature babies birth weight under 1,500 g. Serial blood glucose estimations with mean line. (b) 'Well' premature babies birth weight over $1,500 \mathrm{~g}$. Serial blood glucose estimations: $\triangle$ male, female; with mean line of male and female. (c) 'Well' premature babies birth weight under $1,500 \mathrm{~g}$. Serial serum pentose estimations with mean line. (d) 'Well' premature babies birth weight over $1,500 \mathrm{~g}$. Serial serum pentose estimations: $\Delta$ male, $O$ female; with mean line of both. (e) 'Well' premature babies birth weight under $1,500 \mathrm{~g}$. Serial blood urea estimations with mean line. (f) 'Well' premature babies birth weight over 1,500 g. Serial blood urea estimations: $\triangle$ male, female; with mean line of male and female. (g) 'Well' premature babies birth weight under $1,500 \mathrm{~g}$. Serial plasma. amino acid nitrogen estimations with mean line. (h) 'Well' premature babies birth weight over $1,500 \mathrm{~g}$. Serial plasma amino acid nitrogen estimations: $\Delta$ male, $O$ female; with mean line of both. 


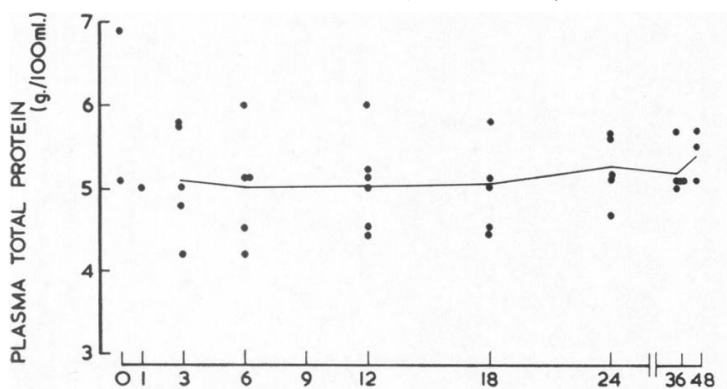

(a)
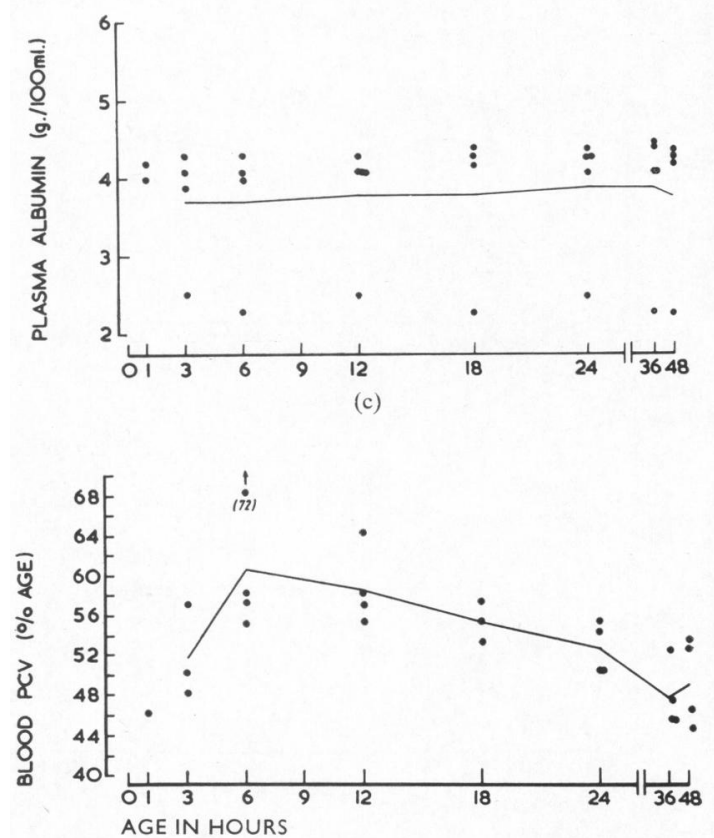

(e)

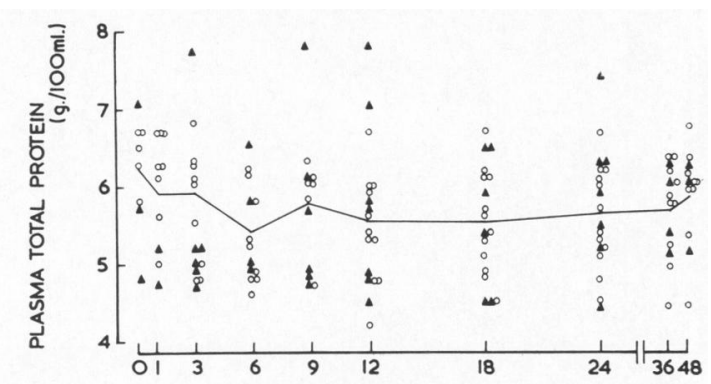

(b)

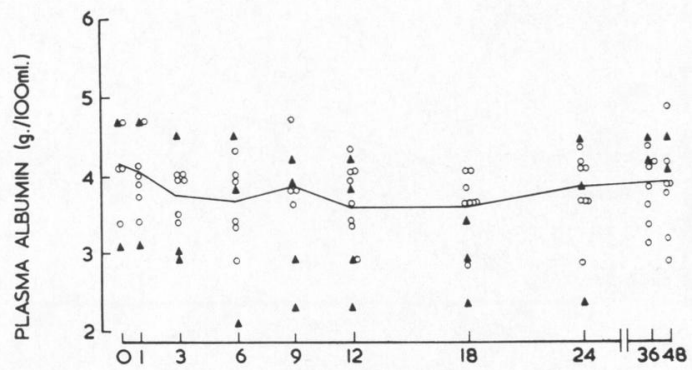

(d)

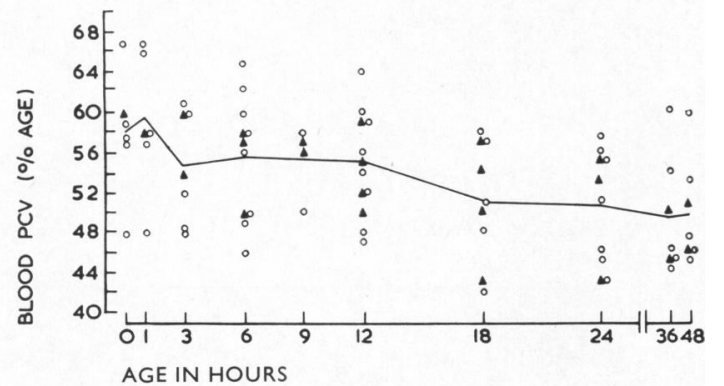

(f)

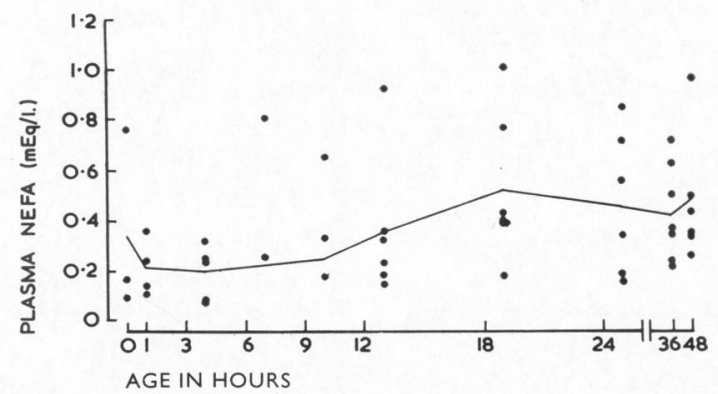

(g)

FIG. 5.-(a) 'Well' premature babies birth weight under 1,500 g. Serial total protein estimations with mean line. (b) 'Well' premature babies birth weight over $1,500 \mathrm{~g}$. Serial total protein estimations: $\Delta$ male, $O$ female; with mean line of both. (c) 'Well' premature babies birth weight under $1,500 \mathrm{~g}$. Serial plasma albumin estimations with mean line. (d) 'Well' premature babies birth weight over $1,500 \mathrm{~g}$. Serial plasma albumin estimations: $\Delta$ male, $O$ female; with mean line of both. (e) 'Well' premature babies birth weight under $1,500 \mathrm{~g}$. Serial packed cell volume estimations with mean line. (f) 'Well' premature babies birth weight over $1,500 \mathrm{~g}$. Serial packed cell volume estimations: $\Delta$ male, $O$ female; with mean line of both. (g) 'Well' premature babies. Serial non-esterified fatty acid estimations with mean line. 
general there was an upward trend during the period of study, so that at 48 hours the serum phosphate was higher than at 24 hours. This peak coincided with the establishment of adequate feeding.

Individual babies maintained their phosphate levels within a narrow range of $1-2 \mathrm{mg} . / 100 \mathrm{ml}$. over the first 2 days.

Glucose. Low glucose levels by adult standards have often been demonstrated in well newborn infants. In our small group of well premature infants weighing less than $1,500 \mathrm{~g}$. every infant had a blood glucose level of $20 \mathrm{mg}$. $/ 100 \mathrm{ml}$. or less at some time during the first 48 hours. These levels usually reached their lowest values from 24-48 hours.

The larger premature infants had significantly higher glucose levels throughout the study period, the means falling between 35 and $45 \mathrm{mg}$. $/ 100 \mathrm{ml}$. A fall during the second 24-hour period was not seen in these bigger infants.

Urea. Cord blood urea values were within the normal adult range but dropped within the first 6 hours of life. There was then a gradual rise over the next 36-48 hours after which a further fall occurred. This occurred at about 24 hours in babies larger than $1,500 \mathrm{~g}$. but at 48 hours in smaller ones. The normal range over the 48 hours was $10-40 \mathrm{mg}$./100 ml., with considerable variation from baby to baby. The trends in urea were preceded by similar trends in amino acid values.

Amino Acid Nitrogen. The mean values for amino acid nitrogen were higher in the smaller premature infants than in the heavier ones, the range being $7 \cdot 9-10 \cdot 2 \mathrm{mg} . / 100 \mathrm{ml}$. as compared with $5 \cdot 4$ $7 \cdot 5 \mathrm{mg}$. $/ 100 \mathrm{ml}$. Individual values up to $16 \cdot 2 \mathrm{mg}$./ $100 \mathrm{ml}$. were seen in well infants.

As with urea values, there was a fall during the first 3-6 hours, then a gradual rise up to 18 hours, then a further fall. These trends preceded the similar changes seen in the blood urea levels.

Pentose. There was a wide range in pentose levels in newborn infants from 2 to $43 \mathrm{mg}$./100 ml., mean values varying from $13 \cdot 7$ to $22 \cdot 8 \mathrm{mg}$. $/ 100 \mathrm{ml}$. In the small number studied, there was no obvious difference between the small and large premature infants. The pentose range in individual babies tended to remain within narrow limits.

Serum Albumin and Globulin. The serum albumin did not vary with birth weight, the means over the first 48 hours ranging from $4 \cdot 1$ to $3 \cdot 5 \mathrm{~g}$. $/ 100 \mathrm{ml}$. Babies heavier than $1,500 \mathrm{~g}$. showed a transient fall in albumin levels at 12-18 hours.
A similar fall was noted in the levels of total globulins, but here there was a difference in the two weight groups; the mean cord level in babies less than $1,500 \mathrm{~g}$. was $1.4 \mathrm{~g} . / 100 \mathrm{ml}$. while that of the heavier babies was $2 \cdot 0 \mathrm{~g}$.

\section{Discussion}

There are no strictly comparable published reports giving the results of serial multiple biochemical estimations on the premature newborn infant over the first 48 hours of life. Our results show that in individual babies a wide range of values may be compatible with a normal clinical progress, but that the levels of each substance studied generally follow a trend over the 48 hours which is common to a particular group of infants. Many babies, particularly those less than $1,500 \mathrm{~g}$., may have biochemical values generally regarded as pathological without showing any symptoms. Whether these values are within the 'physiological range', or whether small infants lack the ability to react to them, one cannot say. The biochemical changes seen in symptomatic newborn babies will be reported shortly.

Acid-base Balance. The immediate problems of extrauterine survival concern respiration and acidbase balance. In the normal adult, acid-base homeostasis is achieved by renal conservation of base with ammonia production, by various buffer systems, and by elimination of carbon dioxide from the lungs. During the first hours of life, renal mechanisms in newborn infants are functioning poorly and at capacity (McCance and von Finck, 1947) and so play little part in acid-base balance.

The trend of the mean $p \mathrm{H}$ in babies of less than $1,500 \mathrm{~g}$. rises more rapidly than that of heavier babies during the first 6-12 hours of life. Almost all the smaller babies show periodic breathing during this time, which has been shown to produce an overall greater ventilation than regular respiration; premature infants with periodic breathing have also been shown to have significantly higher $p \mathrm{H}$ values than those with regular breathing (Chernick, Heldrich, and Avery, 1964); and over this period the fall in $\mathrm{PCO}_{2}$ is steeper in smaller babies. Of the three groups studied here, it is interesting to note that the male infants heavier than 1,500 g. achieve acid-base balance significantly later than females of corresponding weight.

The standard bicarbonate of premature infants stabilizes at a lower level than normal term infants.

The periodic breathing and the resultant hyperventilation may represent attempts by the immature baby to maintain adequate oxygenation in the face 
of possible diffusion deficiencies (Stahlman, 1957), ventilatory deficiencies, and vascular shunts (James and Burnard, 1961). Such a relative hypoxia would explain the higher lactate levels and lower standard bicarbonate levels found in the smaller premature infants. The oxygen tension of well premature infants is about $60-80 \mathrm{~mm} . \mathrm{Hg}$ (J. M. Gupta, 1964, personal communication) and at the lower limits approaches the critical level for lactate production (Huckabee, 1958).

The Parathyroid and Homeostasis. Hormones from the parathyroid have long been known to control calcium and phosphorus metabolism, but their importance in magnesium homeostasis has only recently been investigated (MacIntyre, 1963; MacIntyre, Boss, and Troughton, 1963).

The early trends in serum calcium have been described in newborn term infants by Acharya and Payne (1965) and similar findings have been found in this study. The magnesium values reported are, we believe, the first serial estimations in premature infants. Our levels are generally higher than those of other authors using colorimetric methods, but lie largely within the adult limits defined by Alcock and MacIntyre (1960) using the same spectrophotometric method.

Many hypotheses have been suggested to explain the fall in serum calcium and magnesium after the first 24 hours of life, including that of parathyroid hypofunction. A recent report of neonatal fits associated with hypomagnesaemia (Davis, Harvey, and $\mathrm{Yu}, 1965)$ presents evidence to suggest that there is a transient deficiency in parathyroid activity during the first days of life and that this may result in low levels of calcium and magnesium as found. This deficiency may be demonstrated by the introduction of cows' milk feedings with its added phosphate load.

In this small series, there was no correlation between calcium and phosphorus levels and the values for the two weight groups did not differ significantly. In both groups the level of inorganic phosphorus rose slowly during the 48 hours, a finding already reported by Bruck and Weintraub (1955). This trend probably results from the dietary phosphate load and the diminished parathyroid activity.

Perhaps the most significant feature shown by these routine studies is that low levels of calcium, e.g. $3.2 \mathrm{mEq} / \mathrm{l}$. and magnesium $1.0 \mathrm{mEq} / 1$, may exist in babies who are well and asymptomatic and that such apparently pathological levels may not be the cause of the symptoms that are sometimes attributed to an isolated low reading.
The Electrolytes and Body Water. In premature infants there is a wide range of values for serum sodium and potassium levels. The higher levels are seen in the smaller premature infants and in those exposed to birth stress. The serum sodium level tends to rise slowly over the first 48 hours, presumably as a result of dehydration. The heavier infants over this time show a slow fall in serum potassium from levels that are high by adult standards. These early high levels may exist as a consequence of the acidaemia associated with birth (James, 1960) and glycolysis, their subsequent fall indicating the achievement of acid-base balance and a homeostatic endeavour to maintain ionic balance with sodium.

There is a positive correlation between serum sodium and chloride levels as in adults. The levels of sodium and chloride do not correlate with the changes in packed cell volumes in the small sample obtained, suggesting that haemo-concentration and dilution are occurring independently of changes in the concentration of the extracellular fluid. Any movements between the intra- and extracellular fluids must depend on the cellular sodium and potassium 'pumps'. Little is known about the control of ionic movement in extra renal tissue, but it is likely that steroids influence other cell membranes in addition to those of the nephron cells. Since preliminary results in babies suggest that the adrenal cortex can respond to stress with an increased production of cortisol (W. W. Payne, 1964, unpublished data), it is conceivable that changes in serum electrolytes in well premature infants may be partly steroid dependent.

Another major factor in the distribution of extracellular fluid is capillary permeability. The capillary walls of newly born premature babies leak protein (Usher, 1961), and this movement into tissue fluids may contribute to the transient fall of total serum proteins.

Energy and Substrates. Hypoglucosaemia and its clinical correlates have received much attention recently, and serial values for blood glucose in the newborn are well documented. The trends over the first 24 hours of life are similar in our findings to those of other authors (Baens, Lundeen, and Cornblath, 1963; Ward, 1953) with a rapid fall from cord levels of over $50 \mathrm{mg} . / 100 \mathrm{ml}$. to levels below 35 mg., subsequently. Of our small group of clinically normal babies weighing less than $1,500 \mathrm{~g}$. at birth, all had blood glucose levels less than $20 \mathrm{mg}$./ $100 \mathrm{ml}$. at some time during the first 24 hours of life. Such levels may be in part a reflection of the diminished liver glycogen stores that are found in extremely immature infants (Shelley, 1964): only a 
carefully designed long-term project will show whether these babies are in fact 'well'.

The high amino acid nitrogen values seen in these small babies may result from the need to revert to gluconeogenesis as an energy source until adequate feeding is established. As one might expect if there were protein katabolism, the rise in blood urea lags slightly behind the rise in amino acid nitrogen. After 24 hours the urea level in babies greater than $1,500 \mathrm{~g}$. begins to fall, while that of the smaller babies continues to rise slowly. It is likely that in the second 24 hours of life babies less than 1,500 g. are still receiving inadequate calories by mouth and with smaller initial food stores need to utilize body protein as an energy source.

Insufficient data had been collected to comment on fat metabolism, the last 7 infants only having been studied. From the scanty data, it appears that the non-esterified fatty acid (NEFA) levels in newborn infants lie in the adult range. Of the 7 infants, 2 were less than $1,500 \mathrm{~g}$. at birth and their NEFA levels at 48 hours were 0.38 and $0.27 \mathrm{mEq} / \mathrm{l}$. as compared with a range $0 \cdot 46-1 \cdot 15$ in the 5 heavier infants. The general trend upwards in NEFA levels is in agreement with the values reported by Van Duyne and Havel (1959) for NEFA levels in normal mature newborn infants.

\section{Summary}

Serial chemistry over the first 48 hours of life is reported in 31 premature infants. The pattern of changes in individual parameters of sodium, potassium, chloride, $p \mathrm{H}, \mathrm{PCO}_{2}$, bicarbonate, glucose, pentose, lactate, urea, amino acids, magnesium, calcium, phosphorus, non-esterified fatty acid, and proteins is reported.

Small premature infants achieve acid-base balance following the acidaemia of birth with remarkable rapidity. Other homeostatic mechanisms are, however, slower to function, as is shown by the relative hypocalcaemia and hypomagnesaemia seen at 18-24 hours.

The low glucose levels and the evidence of heightened gluconeogenesis suggest a lack of stored glycogen and fat reserves.

The absence of symptoms in the presence of high potassium, low sugar, low calcium, and low magnesium levels is noted as a characteristic of the newborn and particularly the premature infant.

We would like to thank the Nuffield Foundation and the Sir William Coxen Trust for providing the facilities for this work, Professor J. P. M. Tizard, Dr. J. A. Davis, and the late Dr. M. J. R. Dawkins for their help in the preparation of this paper, and Professor J. P. M. Tizard and Dr. J. A. Davis for access to their patients. We are specially indebted to the Ward Sisters, M. S. Castle, S.R.N., M. Pinder, S.R.N., and J. James, S.R.N., for their great help in the handling of the children.

A part of this was incorporated in a thesis for M. D. London by A.I.

\section{REFERENCES}

Acharya, P. T., and Payne, W. W. (1965). Blood chemistry of normal full-term infants in the first 48 hours of life. Arch. Dis. Childh., $40,430$.

Alcock, N., and MacIntyre, I. (1960). Interrelation of calcium and magnesium absorption. Biochem. J., 76, 19P.

Baens, G. S., Lundeen, E., and Cornblath, M. (1963). Studies of carbohydrate metabolism in the newborn infant. VI. Levels of glucose in blood in premature infants. Pediatrics, 31, 580.

Barker, S. B., and Summerson, W. H. (1941). The colorimetric determination of lactic acid in biological material. J.biol. Chem., $138,535$.

Bruck, E., and Weintraub, D. H. (1955). Serum calcium and phosphorus in premature and full-term infants. Amer.J. Dis. Child., 90, 653 .

Chernick, V., Heldrich, F., and Avery, M. E. (1964). Periodic breathing of premature infants. J. Pediat., 64, 330.

Danielson, I. S. (1933). Amino acid nitrogen in blood and its determination. J. biol. Chem., 101, 505.

Davis, J. A., Harvey, D. R., and Yu, J. S. (1965). Neonatal fits associated with hypomagnesaemia. Arch. Dis. Childh., 40, 286.

Fiske, C. H., and Subbarow, Y. (1925). The colorimetric determination of phosphorus. J. biol. Chem., 66, 375.

Gornall, A. G., Bardawill, C. J., and David, M. M. (1949). Determination of serum proteins by means of the biuret reaction. ibid., $177,751$.

Green, H. N., Stoner, H. B., and Bielschowsky, M. (1949). The effect of trauma on the pentose content of the plasma in animals. J. Path. Bact., 61, 101.

Hill, J. R. (1961). The physics and physiology of the development of homoeothermy. In Ciba Foundation Symposium on Somatic Stability in the Newly Born, ed. G. E. W. Wolstenholme and M. O'Connor, p. 156. Churchill, London.

Huckabee, W. E. (1958). Relationships of pyruvate and lactate during anaerobic metabolism. III. Effect of breathing lowoxygen gases. J. clin. Invest., 37, 264.

James, L. S. (1960). Acidosis of the newborn and its relation to birth asphyxia. Acta paediat. (Uppsala), 49, Suppl. 122, 17.

—- and Burnard, E. (1961). Biochemical changes occurring during asphyxia at birth and some effects on the heart. In Ciba Foundation Symposium on Somatic Stability in the Newly Born, ed. G. E. W. Wolstenholme and M. O'Connor, p. 75. Churchill, London.

Kingsley, G. R. (1939). The determination of serum total protein, albumin, and globulin by the biuret reaction. J. biol. Chem., 131, 197.

McCance, R. A., and von Finck, M. A. (1947). The titratable acidity, $p \mathrm{H}$, ammonia and phosphates in the urines of very young infants. Arch. Dis. Childh., 22, 200.

MacIntyre, I. (1963). Magnesium metabolism. In Sci. Basis Med. Ann. Rev., p. 216.

_- Boss, S., and Troughton, V. A. (1963). Parathyroid hormone and magnesium homoeostasis. Nature (Lond.), 198, 1058.

Marks, V. (1959). An improved glucose-oxidase method for determining blood, C.S.F. and urine glucose levels. Clin. chim. Acta, 4, 395 .

Shelley, H. J. (1964). Carbohydrate reserves in the newborn infant. Brit. med. J., 1, 273.

Stahlman, M. T. (1957). Pulmonary ventilation and diffusion in the human newborn infant. J. clin. Invest., 36, 1081.

Stevens, J. F., and Lanning, K. (1964). Micro $\mathbf{P C O}_{2}$ equilibration unit. Lancet, 2, 447.

Usher, R. H. (1961). The metabolic changes in respiratory distress syndrome of prematurity seen as a failure of somatic compensations for asphyxia. In Ciba Foundation Symposium on Somatic Stability of the Newly Born, ed. G. E. W. Wolstenhome and M. O'Connor. Churchill, London.

Van Duyne, C. M., and Havel, R. J. (1959). Plasma unesterified fatty acid concentration in fetal and neonatal life. Proc. Soc. exp. Biol. (N.Y.), $102,599$.

Ward, O. C. (1953). Blood sugar studies in premature babies. Arch. Dis. Childh., 28, 194. 